\title{
The Preventive Behavior of Green Tobacco Sickness (GTS) Syndrome at Tobacco Farmers: The Role of Health Literacy
}

\author{
Dewi Rokhmah ${ }^{1}, *$ Khoiron ${ }^{2}$ Imas Imama ${ }^{3}$ Nita Indah Lestari ${ }^{4}$ Ahmad Aviv Mahda ${ }^{5}$ Icha \\ Rohmah Damayanti Agustin ${ }^{6}$ \\ ${ }^{1}$ Department of Health Promotion and Behavior Science, Public Health Facult, University of Jembe, Jember, Indonesia, \\ ${ }^{2}$ Department of Environmental Health Public Health Faculty, University of Jember, Jember, Indonesia \\ 3, 4, 5, 6 Magister of Public Health Science, Post Graduate University of Jember, Jember, Indonesia \\ *Corresponding Author email: dewirokhmah@unej.ac.id
}

\begin{abstract}
The purpose of this study was to analyze the correlation between duration of work, smoking status, and knowledge of GTS, and personal hygiene with GTS, status of tobacco farmers, as well as education, knowledge of GTS, income and GTS status of tobacco farmers with health literacy. This research used analytic observational method with cross sectional approach design,conducted in Mayang Sub-district of Jember Regency in October 2017. The sampling technique used purposive sampling method with 30 samples of tobacco farmers. Then, the data analysis used Chi-square test with SPSS 22 software.The results showed that the radio became the most sourcefulof information by 53.3\%. Meanwhile the source of health information from the internet was never reached by all respondents. Health literacy identification showed that $83.3 \%$ of the respondents had poor health literacy, $16.7 \%$ ofothers had sufficient health literacy and no respondents had a good health literacy. There was a significant correlation between the length of work, knowledge of GTS, personal hygiene and GTS status. Meanwhile, there was no significant correlation between smoking status and GTS status $(p=0.0273)$. However, the level of education $(p=$ 0.0001 ) and the knowledge of GTS ( $\mathrm{p}=0.000$ have a significant relationship with health literacy.
\end{abstract}

Keywords: GTS (Green Tobacco Sickness), Health Literacy, Tobacco Farmers, Preventive Behavior

\section{INTRODUCTION}

Tobacco farmers risk to hit occupational diseases which relate to pesticide exposure and absorption of nicotine. Nicotine is the harmful substances in tobacco plants which is able to cause addiction. Nicotine is brought into the human body by smoking, and may also entershrough physical contact with wet tobacco leaves. When nicotine enters the body in much amount it may come some various symptoms that are called Green Tobacco Sickness (GTS) [1]. GTS is a disease that can be caused by the absorption of nicotine on the skin when farmers work in wet tobacco field without using protective tools. The disease is characterized by some symptoms such as headache, nausea, vomiting, and weak [2].

The incidences of GTS in several countries in the world have been studied and showed quite high level. Prospective study by Oliveira et al. (2013) in Brazil, mentioned 107 of 130 sample cases that showed symptoms such as dizziness, headaches, fatigue, nausea and vomiting [3]. According to that prospective study, GTS hashigher trend in the groups of men, nonsmokers and tobacco field workers during harvest. The research by Arcury et al. (2008) in the state of Carolina, United States, reported that $(8.4 \%$ of the 304 tobacco farmers, those positively hit by GTS, showed symptoms of itching and sores on their skin [4]. The related factors of GTS are the age of the groups the time of working in tobacco farm and the activities in tobacco field. GTS in Indonesia have not been done in many researches. A study by Suprapto (2005) on tobacco farmers in the of Temanggung mentioned that the rate of GTS incident reached $63.7 \%$ with found symptoms of dizziness, headache and fatigue. The risk factors, which influenced GTS, included work experience, where the leaves were picked, and the using of protective tools [5].

Jember is one of the largest tobacco-producing areas in Indonesia. In 2011, there were 24,616 tobacco farmers in 14 sub-districtin Jember. The land of tobacco area is 10.009 hectares and it produces amounted to 6,130 tons. Moreover, Jember is a region with high rainfall, ranging from 1,969 mm to $3,394 \mathrm{~mm}$ and humidity ranging between $62-91 \%$ [6]. This is important because GTS is able to hit farmers who work in wet tobacco field that can be caused by rain water or dew in the morning. Nowadays, the research of GTS in Jember have not many been done too many. Whereas, he large number of tobacco farmers and also climatological factors, namely high humidity and rainfall, increase the risk of GTS incidences on tobacco farmers in Jember. 
The data from the study and reference showed that the incidences of GTS on tobacco farmers was high. On the other hand, the research on GTS was too limited. In another way, the tobacco farmers have not many known well about the GTS. According to Soemitro (2014), good knowledge and sufficient income may be associated with the good health literacy [7]. Therefore, researchers are interestedin finding out correlation between the long working, smoking status, knowledge of GTS, and personal hygiene towards GTS status of farmers tobacco and also education, GTS knowledge, income and the status of tobacco farmers with health literacy.

\section{METHODS}

This research was observational analytic, usingross sectional design. The study have been conducted in Mayang, one of the subdistric of Jember which produced tobacco leavesin October 2017. The sampling technique used purposive sampling method with 30 samples of tobacco farmers.This research was conducted by interviewing the respondents and by using questionnaire. The independent variables were education, GTS knowledge, income, long working, smoking status, and personal hygiene, while dependent variables were GTS status and health literacy. Analysis of the data used was univariate and bivariate analyses using Chi-square test with SPSS 22 software.

\section{RESULT}

This research was conducted at Mayang tobacco farmers in Jember. The number of samples in this study were 30 tobacco farmers. The questionnaire that has been filled and recapitulated then was and the results are described as follows:

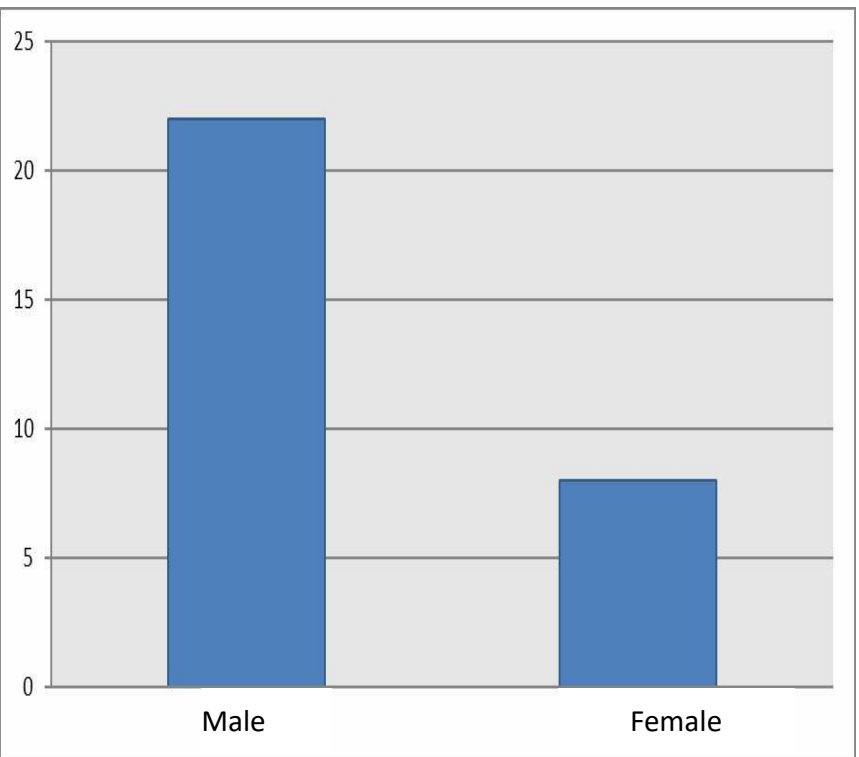

Fig. 1. Distribution of the Sex of Tobacco

Based on the identification by sex in Fig. 1. it is known that the proportion of male respondents as many as $73.3 \%$ or 22 men and that of female respondents is $26.7 \%$ or 8 women.

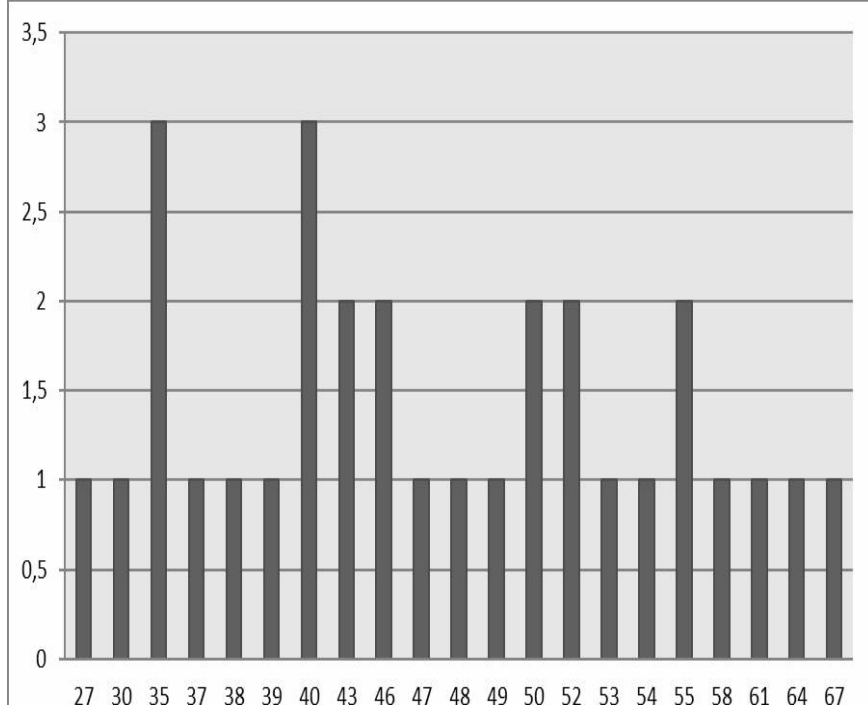

Fig. 2. Distribution of the Age Tobacco Farmers

Based on the results of the identification of the respondents' age in Fig. 2, it is known that the respondens come from various walks of life, ranging from 27 to 67 years old. The average age of the respondents was 46.3 years. Most of age are 35 and 40 years namely respectively consisting of three people $(10 \%)$.

Fig. 3. Distribution of the Marital Status of Tobacco Farmers

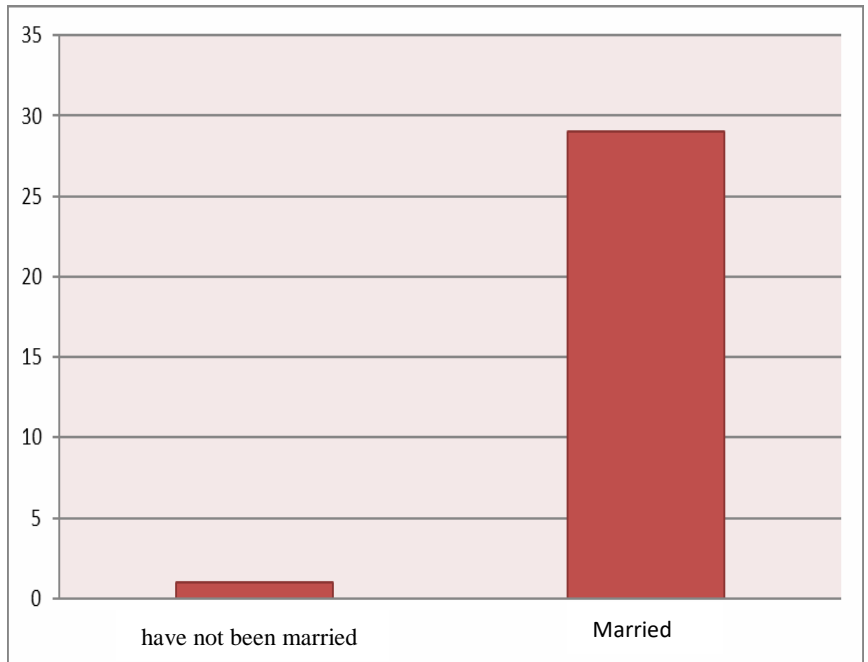

Based on identification of marital status of respondents in Figure 3. it is known that the proportion of respondents who have not been married only $1(3.3 \%)$ and 29 others are married $(96.7 \%)$. 


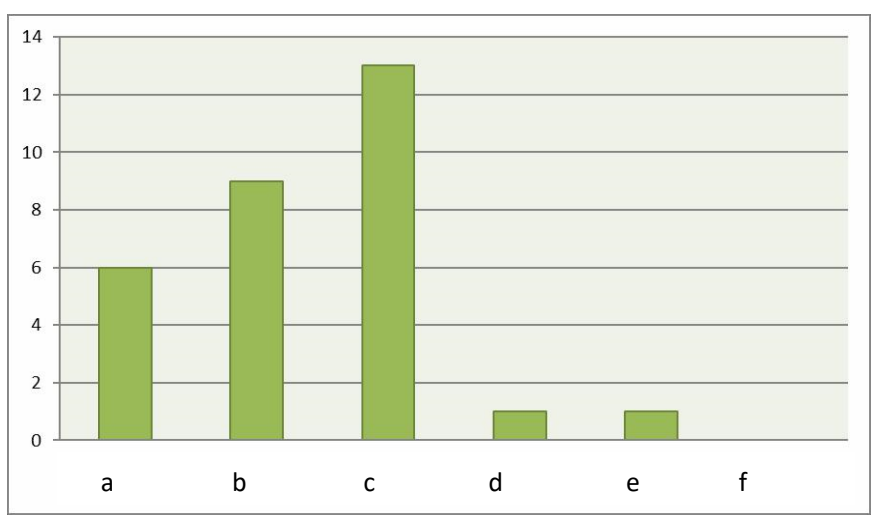

Fig. 4. Distribution of the Last Education of the Farmers

Inf: a :No school, b: Dropout of ES, c: have completed ES, d: Dropout of JHS/SHS, e: have completed JHS/SHS, f: College

Based on the results of the latest education identification of the respondents in Fig. 4, it is known that most respondents have completed elementary school as many as 13 people $(43.3 \%)$ and only 1 person $(3.3 \%)$ who has completed Junior High School/Senior High School.

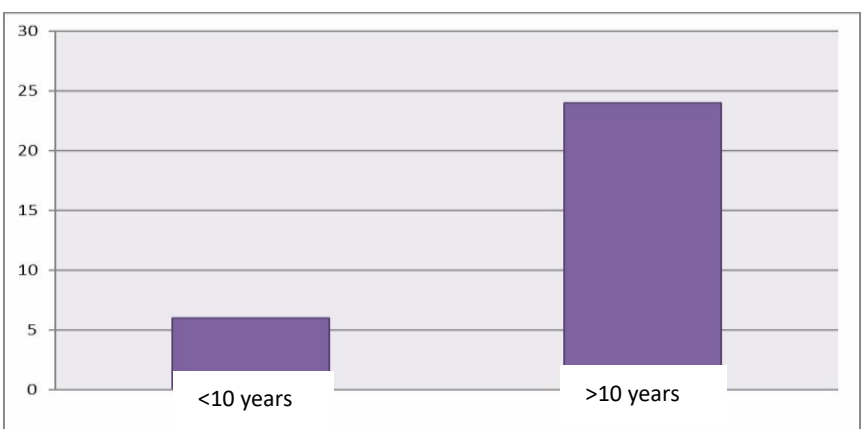

Fig. 5. Distribution of Duration of Working of Tobacco Farmers

The duration of being tobacco farmer has an influence on the length of contact with tobacco leaves which has the potential to increase the risk of getting GTS. Based on the identification of the respondents' working time in Fig. 5, it is reported that most of respondentshave become tobacco farmer for more than 10 years, namely as many as 24 people $(80 \%)$ and the rest $(20 \%)$ have not been in 10 years as tobacco farmer.

* Regional Minimum Income of Jember IDR. 1,763,392.5

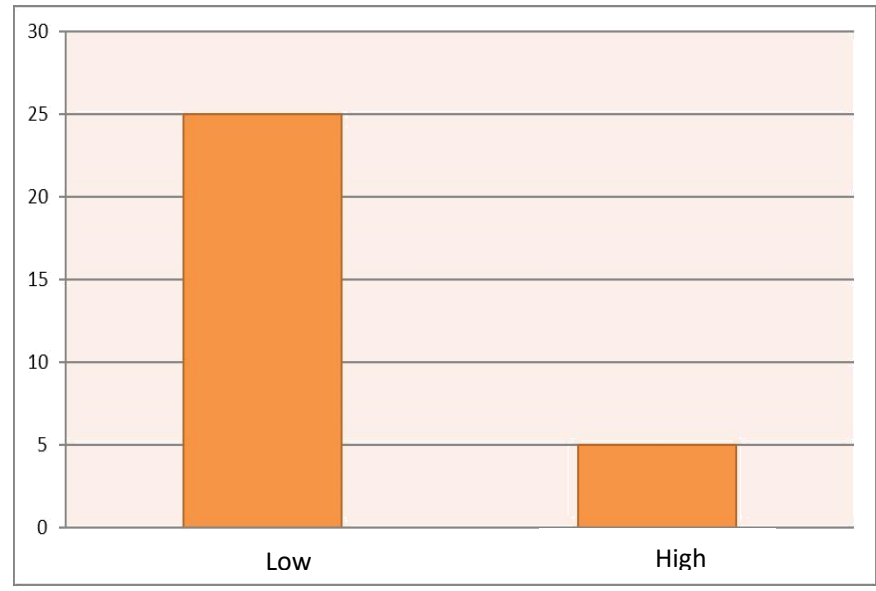

The results of the research experts show that tobacco farmers' income has an impact on their access to education and information about health.Based on the identificationof respondents' income in Fig. 6, it is known that Most of the respondents have low incomes as many as 25 people $(83.3 \%)$ and 5 others have higher income $(16.7 \%)$.

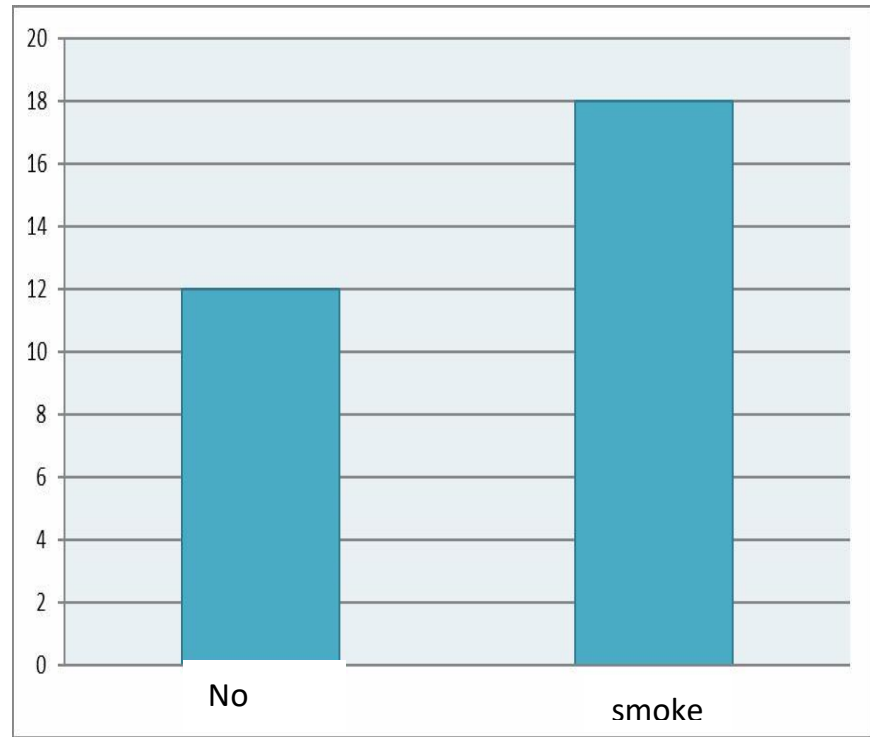

Fig. 7. Distribution of the Smoking Status of Tobacco Farmers

Based on the identification of the smoking status of respondents in Fig. 7, it is known that the proportion of the respondents who smoke is as many as 18 people $(60 \%)$ and the rest or 12 people $(40 \%)$ are not smokers.

Table 1. Distribusition responsible for questions about knowledge of GTS of tobacco farmers

\begin{tabular}{lcccc} 
& \multicolumn{3}{c}{ knowledge of GTS of tobacco farmers } \\
\cline { 2 - 5 } Question & \multicolumn{3}{c}{ Answers } \\
\cline { 2 - 5 } & $\mathbf{n}$ & True & $\mathbf{N}$ & Not true \\
\hline Item 1 & 9 & 30 & 21 & 70 \\
Item 2 & 18 & 60 & 12 & 40 \\
Item 3 & 13 & 43.3 & 17 & 56.7 \\
Item 4 & 7 & 23.3 & 23 & 26.7 \\
Item 5 & 11 & 36.7 & 19 & 63.3 \\
Item 6 & 12 & 40 & 18 & 60 \\
Item 7 & 10 & 33.3 & 20 & 66.7 \\
Item 8 & 15 & 50 & 15 & 50 \\
Item 9 & 11 & 36.7 & 19 & 63.3 \\
Item 10 & 19 & 63.3 & 11 & 36.7 \\
\hline
\end{tabular}

Based on Table 1, it is noted that item 4 is on how nicotine enters the body and item 1 of the GTS is a workrelated illness and is the item that most respondents did not answer correctly. Whereas, item 10 on gloves as a deterrent GTS and item 2 on the farmers with vulnerable GTS are most successful questions answered correctly by respondents.

Respondents were given a score of 0 if they failed to answer the questions correctly and a score of 1 if theysucceeded to answer the items correctly. Total minimum score is 0 and the maximum is 10 . Then, the knowledge about GTS of the respondents were categorized into three categories: bad (score 0-4), fair (score 5-7), and good (score 8-10). The distribution of the respondents' knowledge is presented in Figure 8.

Fig. 6. Distribution of the Income of Tobacco 


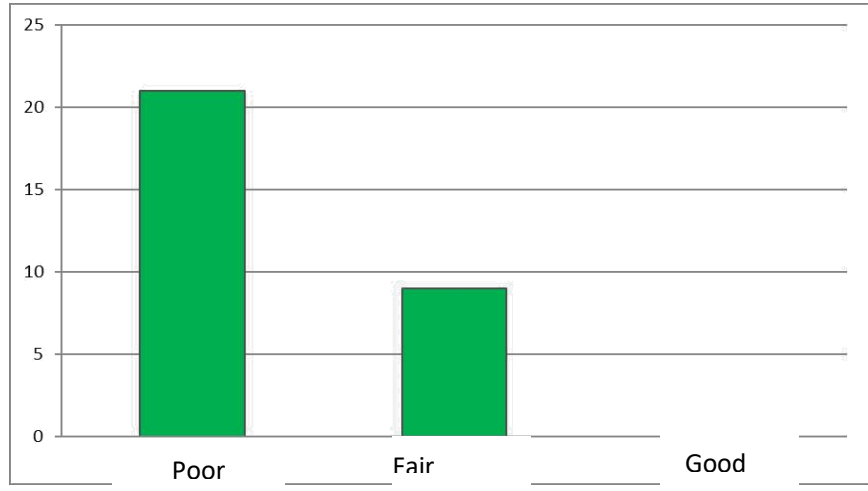

Fig. 8. Distribution of Knowledge about GTS of Tobacco Farmers

Based on the identification of knowledge about GTS in Fig. 8, note that as many as 21 people $(70 \%)$ had a poor knowledge of GTS and 9 people (30\%) others have enough knowledge of GTS. No respondents have a good knowledge of GTS.

Table 2. Distribution of frequency of personal hygiene of tobacco farmers

\begin{tabular}{|l|c|c|c|c|c|c|}
\hline \multirow{2}{*}{ Personal hygiene } & \multicolumn{7}{|c|}{ Frequency } \\
\cline { 2 - 7 } & \multicolumn{2}{|c|}{ Never } & \multicolumn{2}{c|}{ Rarely } & \multicolumn{2}{c|}{ Always } \\
\cline { 2 - 7 } & $\mathbf{n}$ & $\mathbf{\%}$ & $\mathbf{n}$ & $\mathbf{\%}$ & $\mathbf{N}$ & $\%$ \\
\hline $\begin{array}{l}\text { Washing hands after } \\
\text { working in the field }\end{array}$ & 6 & 30 & 17 & 56.7 & 7 & 23.3 \\
\hline $\begin{array}{l}\text { Washing hands with soap } \\
\text { and running water }\end{array}$ & 10 & 33.3 & 15 & 50 & 5 & 16.7 \\
\hline $\begin{array}{l}\text { Taking shower with soap } \\
\text { after working in the field }\end{array}$ & 2 & 6.7 & 13 & 43.3 & 15 & 50 \\
\hline $\begin{array}{l}\text { Changingof clean clothes } \\
\text { after working in the garden }\end{array}$ & 1 & 3.3 & 15 & 50 & 14 & 46.7 \\
\hline $\begin{array}{l}\text { Washing clothes that have } \\
\text { been wornto work in the } \\
\text { field }\end{array}$ & 19 & 63.3 & 4 & 13.3 & 7 & 23.3 \\
\hline
\end{tabular}

Based on Table 2, it is known that the majority of respondents $(56.7 \%)$ rarely wash hands after working in the garden. Most respondents $(63.3 \%)$ never wash clothes that have been wornto work in the field. However, half of the respondents always take a shower with soap after working in the field.

Score of 0 is given if the respondents never have personal hygiene, a score of 1 if they rarely do, and a score of 2 when they always do. Total minimum score is 0 and maximum is 10. The personal hygiene of therespondents were categorized into three categories: bad (score 0-4), fair (score 5-7), and good (score 8-10). The distribution of personal hygiene category of the respondents is presented in Figure 9.

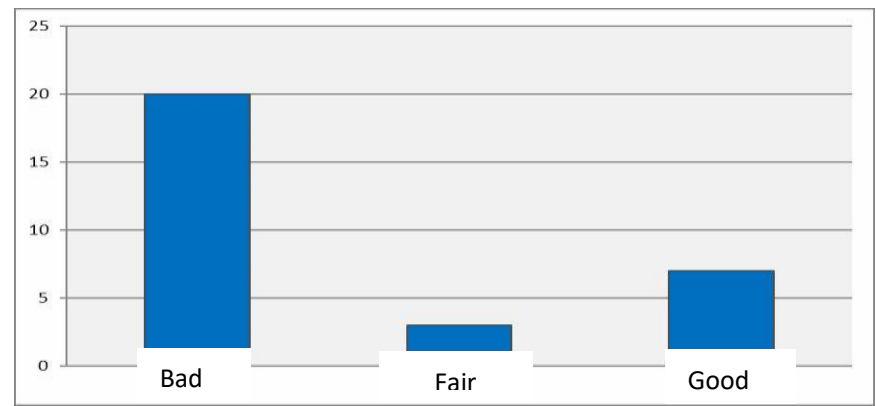

Fig. 9. Distribution of Personal Hygiene of Tobacco Farmers
Based on the identification of other personal hygiene of the respondents in Fig. 9, it is known that as many as 20 people $(66.7 \%)$ have bad personal hygiene, 3 people $(10 \%)$ have considerable personal hygiene, and the rest or 7 people $(23.3 \%)$ have personal good hygiene.

Table 3. Distribution of GTS symptoms of tobacco farmers

\begin{tabular}{|l|c|c|c|c|}
\hline \multirow{2}{*}{ Symptoms of GTS } & \multicolumn{4}{|c|}{ Ever experienced } \\
\cline { 2 - 5 } & \multicolumn{2}{|c|}{ Yes } & \multicolumn{2}{c|}{ No } \\
\cline { 2 - 5 } & $\mathbf{n}$ & $\mathbf{\%}$ & $\mathbf{n}$ & \% \\
\hline Nausea & & & & \\
\hline Vomiting & 12 & 40 & 18 & 60 \\
\hline Shortness of Breath & 3 & 10 & 27 & 90 \\
\hline Headache & 20 & 66.7 & 10 & 33.3 \\
\hline Encourage & 22 & 73.3 & 8 & 26.7 \\
\hline Limp & 16 & 53.3 & 14 & 46.7 \\
\hline Excessive sweating & 6 & 20 & 24 & 80 \\
\hline Shivering & - & - & 30 & 100 \\
\hline Seizures & - & - & 30 & 100 \\
\hline Skin itching and sores & 19 & 63.3 & 11 & 36.7 \\
\hline
\end{tabular}

Based on Table 3, it is known that the GTS symptoms most commonly experienced by the respondents are dizziness $(73.3 \%)$, headache $(66.7 \%)$, as well as itching and skin lesions $(63.3 \%)$. Chills and seizures are symptoms of GTS never experienced by the respondents.

Score of 0 is given if the respondents havenever experienced symptoms of GTS and a score of 1 if experiencing symptoms of GTS. Total minimum score was 0 and the maximum is 10 . Then, total score was used to assess the status of the respondents of GTS. GTS status of the respondents was categorized into two categories i.e.The first category, if the respondent does not experience symptoms of GTS, the score is less than $3(<3)$ and the second category if the respondent experiences GTS symptoms, the score is 3 or more than $3(\geq 3)$. The distribution of GTS status category of the respondents was presented in Chart 10 .

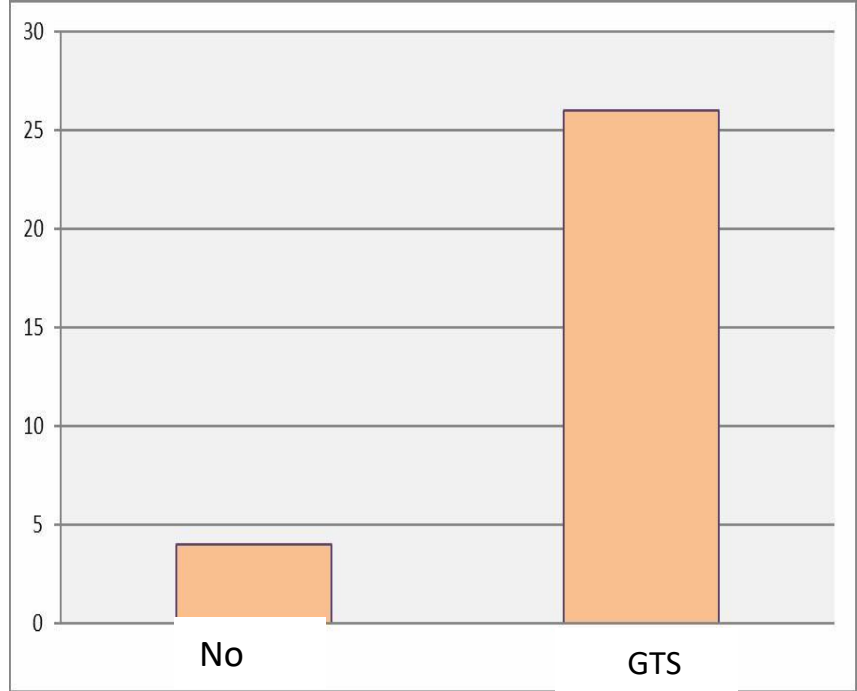

Fig. 10. Distribution of GTS Status of Tobacco Farmers

Based on the identification of GTS status of the respondents in Fig. 10, it is known that almost all respondents experienced GTS as many as 26 people $(86.7 \%)$ and 4 other $(13.3 \%)$ had no GTS. 
Table 4. Distribution of information sources as health literacy of tobacco farmers

\begin{tabular}{|l|c|c|c|c|c|c|c|c|}
\hline \multirow{2}{*}{$\begin{array}{c}\text { Source of } \\
\text { information as } \\
\text { health literacy }\end{array}$} & \multicolumn{2}{|c|}{ No } & \multicolumn{6}{|c|}{ Yes } \\
\cline { 2 - 9 } & $\mathbf{n}$ & $\mathbf{\%}$ & $\mathbf{N}$ & $\mathbf{\%}$ & $\mathbf{n}$ & $\mathbf{\%}$ & $\mathbf{n}$ & $\mathbf{\%}$ \\
\hline Print media & 21 & 70 & 6 & 20 & 2 & 6.7 & 1 & 3.3 \\
\hline Radio & 14 & 46.7 & 10 & 33.3 & 5 & 16.7 & 1 & 3.3 \\
\hline Television & 17 & 56.7 & 9 & 30 & 3 & 10 & 1 & 3.3 \\
\hline Internet access & 30 & 100 & - & - & - & - & - & - \\
\hline Health workers & 23 & 76.7 & 3 & 10.0 & 4 & 13.3 & - & - \\
\hline $\begin{array}{l}\text { Agricultural } \\
\text { extension }\end{array}$ & 21 & 70 & 3 & 10 & 5 & 16.7 & 1 & 3.3 \\
\hline Farmers & 21 & 70 & 6 & 20 & 3 & 10 & - & - \\
\hline $\begin{array}{l}\text { Community } \\
\text { meeting }\end{array}$ & 23 & 76.7 & 4 & 13.4 & 3 & 10 & - & - \\
\hline
\end{tabular}

Based on Table 4, it is known that radio is the most frequently used healthy resource by respondents as many as 16 people $(53.3 \%)$, while the source of health information from the Internet is never reached by all respondents.

Score 0 is given if the respondents never reach the source of health information, a score of 1 if only reaching health resources as much as one, a score of 2 when health resources reach as many as 2-3 times, and a score of 3 when reaching health information source for more than three times. Total score of the least is 0 and the maximum is 24 . Then the total score was used to assess health literacy respondents. Then, the health literacy of the respondents was categorized into three that is bad (score 0-8), fair (score 9-16), and good (score 17-24). Distribution of the category of health literacy of the respondents is presented in Diagram 11.

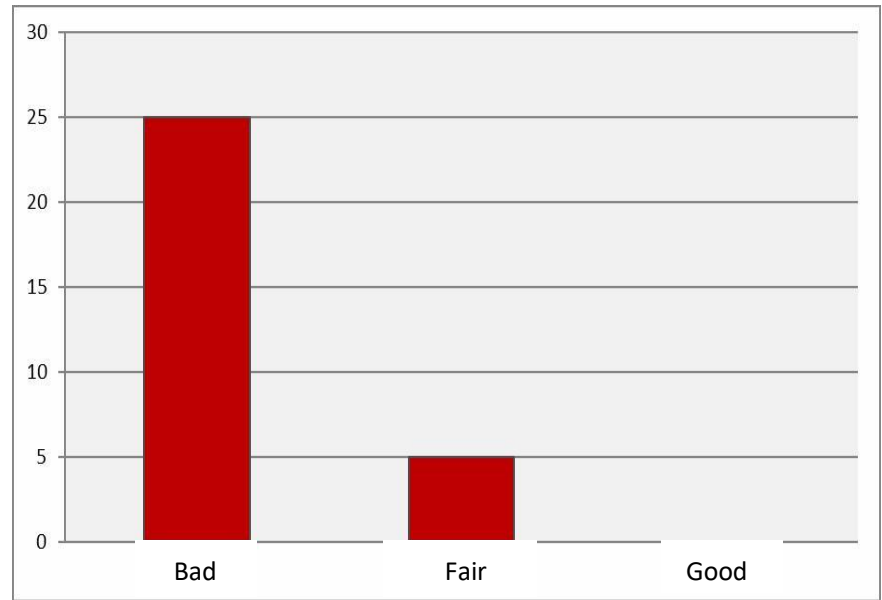

Fig. 11. Distribution of Health Literacy of Tobacco Farmers

Based on the identification of health literacy of of the respondents in Fig. 11, it is known that as many as 25 people $(83.3 \%)$ had a poor health literacy and $5(16.7 \%)$ othershad sufficient health literacy. No respondents had the good health literacy.

Table 5. The Correlation of Work Long, Smoking Status, GTS Knowledge, and Personal Hygiene with GTS Status

\begin{tabular}{||l|c|c|l|}
\hline $\begin{array}{c}\text { The independent } \\
\text { variable }\end{array}$ & $\begin{array}{c}\text { Dependent } \\
\text { variable }\end{array}$ & $\begin{array}{c}\text { Values of } \\
\text { significance } \\
(\mathbf{p})\end{array}$ & \multicolumn{1}{|c|}{ Information } \\
\hline Length of working & GTSStatus & 0.000 & There was a correlation \\
\hline Smoking status & GTS Status & 0.273 & There was no correlation \\
\hline Knowledge of GTS & GTS Status & 0.028 & There was a correlation \\
\hline Personal Hygiene & GTSStatus & 0.000 & There was a correlation \\
\hline
\end{tabular}

Based on Table 5, the results the statistical test to length of work, knowledge of GTS, personal hygiene and GTS status showedthe value of $p=(0.05)$, which meantthere was no significant correlation between smoking status and the status of the GTS.

Table 6. The correlation Education Level, Knowledge of GTS, and Revenue byHealth Literacy

\begin{tabular}{|l|c|c|lc|}
\hline \multicolumn{1}{|c|}{$\begin{array}{c}\text { The independent } \\
\text { variable }\end{array}$} & $\begin{array}{c}\text { Dependent } \\
\text { variable }\end{array}$ & $\begin{array}{c}\text { Values of } \\
\text { significance } \\
(\mathbf{p})\end{array}$ & Information \\
\hline Level of education & Health literacy & 0.001 & $\begin{array}{l}\text { There was a } \\
\text { correlation }\end{array}$ \\
\hline knowledge of GTS & Health literacy & 0.000 & $\begin{array}{l}\text { There was a } \\
\text { correlation }\end{array}$ \\
\hline Income & Health literacy & 0.000 & $\begin{array}{l}\text { There was a } \\
\text { correlation }\end{array}$ \\
\hline Status of GTS & Health literacy & 0,000 & $\begin{array}{l}\text { There is a } \\
\text { relationship }\end{array}$ \\
\hline
\end{tabular}

Based on Table 6 , the results of statistical tests on the level of education and Health Literacy showed the value of $p$ $=0.001 \quad(<0.05)$, which meant there was significant relationship between health education and literacy levels. The results of the statistical test to knowledge of GTS and health literacy showedthe value of $p=0.000(<0.05)$, which meant there was a significant correlation between GTS and health literacy knowledge.

\section{DISCUSSION}

Based on the research results, the majority of the respondents have been tobacco farmers for more than 10 years, consisting of of 24 people $(80 \%)$. The result of chisquare test showed the correlation $(\mathrm{p}=0.000)$ between the length of the work and GTS status. Kau \& Kusnanto (2017) said that one of the factors that influenced the occurrence of GTS in tobacco farmers wasworking period [8]. The result showed that working period hada significant correlation $(\mathrm{p}<0.05)$. This is consistent with the research by Tulus (1992) [9]. Tulus said that length of the work was able to affect the positive or negative effect of working performance. The positive effect will be felt by the person working with a long duration, and it is good to increase the experience of the job. On the other hand, the lengthof the work will give negative impact such as bad habits of the labor. The tobacco farming activities which are not done well will cause to the possibility ofmaking someone havethe symptoms of Green Tobacco Sickness, which is able to decrease the efficiency and productivity or working. Hoang, et al. (2000) GTS is characterized by symptoms that may include nausea, vomiting, weakness, headache, dizziness, abdominal cramps, and difficulty in breathing, as well as fluctuations in blood pressure and heart rate [10]. Large and frequent applications of pesticides to protect the plant from insects and diseases can cause poisoning, skin and eye irritation and other disorders of the nervous, respiratory systems, as well as kidney damage. According to research before by Rokhmah and Khoiron (2014) there are $66.3 \%$ of tobacco farmers who have GTS symptoms [11]. Statistical tests showed that there were influences between the sexes $(p=0.022)$ and time been tobacco farmer $(\mathrm{p}=0.025)$ as well as preventive behavior of GTS ( $p=0.002$ ) on the occurrence of GTS symptoms on tobacco farmers. Table 5 and 6 has beed added the eksplanation of the class. 
The results showed that the proportion of the respondents who smoked were bigger than that of who did not smoke, consisting of 18 people $(60 \%)$. The result of chi-square test showed no correlation $(\mathrm{p}=0.273)$ between smoking status and the status of GTS. Nicotine in ciggaretes enters the human body through the respiratory tract, while the GTS is caused by nicotine that enters the human body through the skin. It is confirmed by the research of McBridege et al. (1998) that the symptoms of Green Tobacco Sickness (GTS) on tobacco farmers are caused by absorption of nicotine from wet tobacco leaves through the skin of the farmers [12]. The treatment of Green Tobacco Sickness (GTS) on tobacco farmers can be pursued by reducing contact with the wet leaves and by creating the environment condition which is not humid. In addition, based on the research by Kau \& Kusnanto (2017) about the other treatment to protect from GTS, tobacco farmers can use personal protective equipment, especially gloves [8]. Arcury and Quandt's research (2006) mentions the health effects of tobacco production, namely nicotine poisoning (green tobacco sickness), exposure to pesticides, respiratory effects, musculoskeletal and other injuries [13]. Most research has focused on nicotine poisoning.

The majority of respondents, or 21 people (70\%), have had low knowledge of GTS. The result of chi-square test showed correlation $(p=0.028)$ between knowledge of GTS and GTS status. This is supported by Rogers in Notoatmodjo (2007), showing that cognitive knowledge is the dominant one which is very important to form the attitude of a person (overt behavior) [14]. The behavior which is based on the knowledge will be more durable than the one that are not. Gudded et al.(2012) state that the impact of good knowledge is that someone can avoid illness, but if the knowledge is low, the person might not be able to avoid it [15]. Knowledge related to health problems will affect the occurrence of health problems in certain groups. Low knowledge about GTS will result in reduced ability to prevent and to handle GTS Research Saleeon, et al. (2015) almost all farmers graduate from primary school and farming is their traditional occupation [16]. It should be noted that although the health effects of growing tobacco are known by these farmers, they do not recognize the route of effect or cause of known health problems. For all these reasons, a health education program that addresses the reduction in health risk exposure is recommended.

The research showed that most respondents $(63.3 \%)$ have never washed clothes that were worn to work in the field. The resultof chi-square test showed the correlation $(p=0.000)$ between the personal hygiene and GTS status showing the impact on the case of symptoms of Green Tobacco Sickness (GTS) on tobacco farmers. This is consistent with the research by Rokhmah (2013) [17]. The causes of tobacco farmers in Jember have not been given with action for the prevention of GTS, especially related to personal hygiene behavior. This means that tobacco farmers are still rare or have not done the prevention of GTS symptoms yet. This condition occurs because they have not been exposed with the information about the risk factors of GTS and the lack of ability of tobacco farmers in the procurement of PPE when working in the tobacco field. This statement is also supported by Shailee and Vikas (2017), that wearing work clothes that have become wet from dew or perspiration may increase exposure and absorption of nicotine through the skin [18]. So,it causes tobacco farmers to be more susceptible to Green Tobacco Sickness (GTS). In line with the research of Ballard, et al. (1992) problems among tobacco workers can be prevented by avoiding working in wet tobacco or by wearing protective clothing [19]. Achalli et al. (2012) the use of protective clothing, waterproof clothing, chemical resistant gloves, plastic aprons and raincoats with boots and socks has reduced the possibility of contracting GTS [20].

The results showed that only 1 respondent has completed junior high school and most of the respondents (43.3\%) have just graduated from elementary school. The result of chisquare test showed the correlation $(\mathrm{p}=0.000)$ between last education and health literacy. The level of education takes many effects in health literacy, in which someone cannot apply the information well because the ability to read, to understand, and to analyze is low. It is relatively unknown by someone who has low level education. It is because the person who has low education level has difficulties in using the information analyzed to determine a good decision for high health. Someone must have a good basic understanding ability (good literacy) to be able to process the information obtained actively [21]. This is consistent with the research by Soemitro (2014) showing that the causes of low health literacy are the age and level of education [7].

The majority of the respondents, or 21 people (70\%), had the low knowledge of GTS. The result of chi-square test showed a correlation $(\mathrm{p}=0.000)$ between GTS knowledge and health literacy. Knowledge is the result of knowing and happening after people do a specific sensing of objects. Human will use the senses of sight, hearing, smell, taste, and touch. Most of the human knowledge is obtained through the eyes and ears [14]. Knowledge can be acquired either formally or informally. Formal knowledge can come from education at school, while the informal knowledge can come from vorious of sources for the example: electronic media such as television, radio and internet and printed media like books, newspapers, magazines, and banners, and also can be obtained from the experience, training, counseling, and others.

The majority of the respondents, or 25 people $(83.3 \%)$, had low income. The result of chi-square test showed a correlation $(p=0.000)$ between income and health literacy. This is supported by the research of Soemitro (2014), which mentioned that the good knowledge and sufficient income could relate with good health literacy [7]. Simmich (2009) showed that economic factors could affect a person's ability to get health services so that it could influence someone in understanding and in accessing health information [22]. The research by $\mathrm{Ng} \&$ Omariba (2010) also showed that there wasa correlation between low income and health literacy [23]. According to the research by Rokhmah and Khoiron (2014) said that associated with GTS symptoms complaints, most farmers claimed to have been accustomed to suffered dizziness and nausea at the morning when in the tobacco field [11]. They experienced this incident between 8 to 10 o'clock in the morning.

The results showed that the majority of the tobacco farmers have been $(86.7 \%)$ have been hit by GTS and most of them $(83.3 \%)$ had low health literacy. The result of chi-square test showed a correlation $(\mathrm{p}=0.000)$ between the status of 
GTS and health literacy of the farmers. It meant that GTS which happened to the tobacco farmers could be related to health literacy.Someone with a low level of literacy tends to have low knowledge. The impact of a low level of health literacy is a worse health status [24]. Health literacy in each individual is important to know because it relates to the ability to obtain health information, to improve health knowledge and to help individuals or communities to make appropriate decisions about health [25].

Most of the tobacco farmers have low health literacy. They mentioned some tobacco farmers expressed some obstacles that made them difficult to get health literacy such as low of counseling and discussion about health. According to the farmers, health workers in their region are still scarce to do the health counseling. In addition, health workers have not reached the remote villages to meet the tobacco farmers in order to provide health information. This condition is the same with the results of the study by Rokhmah et al (2019) said that majority of tobacco farmers had an education level of elementary and had an income below the minimum wage [26]. This has an impact on their financial ability to access adequate health care is lacking

Beside those situation, the groups of the farmers have not existed yet so much. It makes the meetings or discussions among the farmer group members are also very rarely done, especially to discuss or to talk about health. There are also obstacles that come from themselves, such as the bustle work, feeling dhyand being lazy to get health information, and inadequate ability of using technology. Tobacco farmers hope that they have good health literacy from health workers and that the farmers' group can hold local counseling and discussion about health more often.

\section{CONCLUSION}

The length work, GTS knowledge, and personal hygiene have correlation with the symptoms of GTS on tobacco farmers.The education, GTS knowledge, and the personal income also have correlationwith health literacy of the tobacco farmers. The majority of the tobacco farmers $(86.7 \%)$ have been hit by GTS and the large number of them $(83.3 \%)$ have had lowest health literacy.There is a correlation between the symptoms of GTS and health literacy of the tobacco farmers. There are some suggestions for the improvement of the tobacco farmers, such as the extension and discussion about health are more often held by workers health, farmer groups and both cooperation. Then, the distribution of information media health is more equal throughout the village. Moreover, the tobacco farmers must have a great desire to obtain health information.

\section{ACKNOWLEDGMENT}

The researchers express their gratitude to: Faculty of Public Health Jember University, and Master's Program of Public Health Sciences Jember University that support in carrying out this research, as well as to all field surveyor teams that have assisted with the collection of data during the research. Many thanks also go to all of the tobacco farmers at Jember Regency as the respondents of this research.

\section{REFERENCES}

[1] Blosser, F. 1993. NIOSH Issue Warning to Tobacco Harvesters. CDC- NIOSH. [Serial Online]. http://www.cdc.gov/mmwr/PDF/wk/mm4213.pdf $[10$ Oktober 2017].

[2] McKnight, R.H. Spiller, H.A. 2005. Green Tobacco Sickness in Children and Adolescent. Public Health Report/November-December/Volume 120.

[3] Oliveira, P.P.V. 2010. First Reported Outbreak of Green Tobacco Sikness in Brazil [Online]. http://portal.saude.gov.br/portal/arquivos/pdf/artigodoen cafolhaverdearapiraca.pdf. [10 Oktober 2017].

[4] Arcury T.A, Quandt S.A, Preisser J.S, Norton D. 2005. The Incidence of Green Tobacco Sickness and Skin Integrity among Migrant Latino Farmworkers. Journal Occupacional Environment Medical 2001;43:601- 9.

[5] Suprapto, S. 2005. Insiden dan Faktor Risiko Green Tobacco Sicknes (GTS) pada Petani Pemetik Daun Tembakau di Desa Bansari, Kecamatan Parakan. Kabupaten Temanggung Jawa Tengah.Tesis. Universitas Indonesia. [serial online]. http://lontar.ui.ac.id/opac/themes/libri2/detail.pdf $\quad[10$ Oktober 2017]

[6] BPS Jember. 2010. Jember Dalam Angka 2010. Jember: Badan Pusat Statistik.

[7] Soemitro, H. 2014. Analisis Tingkat Health Literacy Dan Pengetahuan Pasien Hipertensi Di Puskesmas Kabupaten Malang. Jurnal Ilmiah Mahasiswa Universitas Surabaya Vol.2 No.01.

[8] Kau, A., Kusnanto, H. 2017. Prevalensi Kasus Green Tobacco Sickness Pada Pekerja Petani Tembakau di Bantul. BKM Journal of Community Medicine and Public Health. [Serial Online]. https://pdfs.semanticscholar.org/c9ee/2358c7c6026be64 0ed2ce24483a7d684b1ce.pdf [22 Juli 2019].

[9] Tulus, A. 1992. Manajemen Sumber Daya Manusia. Jakarta: PT. Gramedia Pustaka Utama.

[10] Hoang Van Minh, Kim Bao Giang, Nguyen Ngoc Bich, Nguyen Thanh Huong. (2009) Tobacco farming in rural Vietnam: questionable economic gain but evident health risks. BMC Public Health 9:1.

[11] Rokhmah D, Khoiron . 2014. Risk Factor Analysis Of Green Tobacco Sickness (GTS) And The Handling Method On Tobacco Farmers International Journal of Current Research And Academic Review (IJCRAR) Special Issue (1) Oktober 2014 pp 20-29.

[12] Mc Bridge, J.S. Altman, D.G. Klein, M. White. Green Tobacco Sickness. Tobacco Control. 2001; 21:191-196. http://tobacco.control.bmj.com/

[13] Arcury, T. A. and Quandt, S. A. 2006. Health and Social Impact of Tobacco Production. Journal of Agromedicine. 11 (3-4) : (71-81).

[14] Notoatmodjo, S. 2007. Pendidikan dan Perilaku Kesehatan. Jakarta: Rineka Cipta.

[15] Guddad S, Malagi U, Kasturiba B et al, 2012, Knowledge and Life Style Factorsof Hypertensive Subjects, Karnataka J. Arigc. Sci., 25 (3): (373-376).

[16] Saleeon, T. Siriwong, W. Perez, H.L.M. Robson, M.G. 2015. Green Tobacco Sickness among Thai Traditional Tobaccp Farmers, Thailand. Journal of Occupational and Environmental Medicine. Volume 6.

[17] Rokhmah, D. 2013. Analisis Faktor Risiko Green 
Tobacco Sickness (GTS) Dan Metode Penanganannya Pada Petani Tembakau. Jember: FKM Universitas Jember.

[18] Shailee \& Vikas. 2017. Green Tobacco Sickness: A Brief Review. Indian Journal of Occupational And Enviromental Medicine. [Serial Online]. https://www.ncbi.nlm.nih.gov/pmc/articles/PMC586808 2/ [23 Juli 2019].

[19] Ballard, T. Ehlers, J.M. Freund, E. Auslander, M. Brandt, V. Halperin, W.1992.Green Tobacco Sickness: Occupational Nicotine Poisoning in Tobacco Workers. Journal of Environmental and Occupational Health.50 (5) : (384-389).

[20] Achalli, S. Shetty, S.R. Babu S.G. 2012. The Green Hazards: A Meta-Analysis of Green Tobacco Sickness. Journal Archives of Environmental and Occupational Health. Volume 2 (1).

[21] Sorensen K., Broucke SV, Fullam et al. 2012. Health Literacy and Public Health: A Systematic Review and Integration of Definitions and Models. BMC Public Health, 12: 80.

[22] Simmich. 2009. Health Literacy And Immigrant Population. Ottawa: Public Health Agency of Canada And Metropolis Canada. [Serial Online]. http://www.metropolis.net/pdfs/health_literacy_policy brief jun15 e.pdf. [22 Juli 2019]

[23] Ng, E., Omariba, DW. 2010. Health Literacy And Immigrants In Canada: Determinant And Effect On Heath Outcomes. Canadian Coincil on Learning. Canada.

[24] Institute of Medicine. 2004. Health Literacy. A perception To End Confusion Washington DC: National Academic. [Serial Online]. https://www.researchgate.net/profile/Lynn_NielsenBohlman/publication/303697782_Health_Literacy_A P rescription to End_Confusion/links/574e41d208ae8bc5 d15bfda9/Health-Literacy-A-Prescription-to-EndConfusion.pdf. [22Juli 2019].

[25] Gani, N., Kadar, K., Kaelan, C. 2017. Health Literacy And Self Care Management of Pregnant Woman At Level 1 Healh Service in Makassar. Indonesia Contemporary Nursing Journal.[Serial Online].http://journal.unhas.ac.id/index.php/icon/article/ download/3592/2130[22Juli 2019].

[26] Rokhmah D. Ma'rufi I, Khoiron. 2019. IOP Conference Series: Earth and Environmental Science 243 (2019) 012090. doi:10.1088/1755-1315/243/1/012090 